it revealed wide community support for the legality of the measures employed by the United States.

Crities of the self-defense argument contend that self-defense is too dangerous an instrument, and therefore the United Nations Charter must be so construed as to forbid its invocation. But the alternatives seem even more dangerous. Conceding, as these critics do, that states whose survival is threatened will nonetheless react to such threats, such responses will then be either outside or above the law. Surely, this cannot be more desirable. The measures employed by the United States were not "preventive war." They were moderate measures, skillfully executed, whose purpose was to prevent war. Under all the circumstances, factual and legal, the quarantine of Cuba constituted substantial compliance with both the spirit and the content of the principles and procedures of the world community.

Brunson MacChesney

\title{
THE SOVIET-CUBAN QUARANTINE AND SELF-DEFENSE
}

In an article appearing elsewhere in this issue Professor Quincy Wright concludes-among many other things, most of which are largely dependent upon this particular conelusion-that the quarantine imposed by the United States in Oetober, 1962, upon the importation of offensive weapons into Cuba eannot be regarded as a lawful exercise by the United States of the right of self-defense. This conclusion Professor Wright seeks to establish by interpreting Article 51 of the United Nations Charter as limiting the traditional right of self-defense by states to reactions against "actual armed attack." Such an interpretation enables him, since the United States acted before any actual firing of the weapons, to avoid the difficult task of a careful appraisal of the United States' measure for its necessity and proportionality in total context. With greatest deference to Professor Wright, it may be suggested both that his conclusion is not a necessary one and that his reasoning is inimical to appropriate clarification under contemporary conditions of the common interest in a viable minimum world public order.

The broad outlines of a different approach may be indicated by briefly noting, first, the more important characteristics of the traditional, customary right of self-defense, secondly, the considerations which should guide a genuine, as contrasted with a spurious, interpretation of the whole United Nations Charter, and, thirdly, the more obvious factors in the context of this particular confrontation between the United States and the Soviets which should be taken into account in any serious assessment of the necessity and proportionality of the United States' action.

Historically, states have demanded, and reciprocally honored, a right of self-defense of considerable, though not unlimited, scope. In broadest formulation, this right of self-defense, as established by traditional practice, authorizes a state which, being the target of activities by another state, reasonably decides, as third-party observers may determine reason- 
ableness, that such activities imminently require it to employ the military instrument to protect its territorial integrity and political independence, to use such force as may be necessary and proportionate for securing its defense. ${ }^{1}$ In a still primitively organized world in which expectations are low about the effective capability of the general community to protect its individual members, this right has been regarded as indispensable to the maintenance of even the most modest minimum order.

The more important limitations imposed by the general community upon this customary right of self-defense have been, in conformity with the orerriding policy it serves of minimizing coereion and violence across state lines, those of necessity and proportionality. The conditions of necessity required to be shown by the target state have never, however, been restricted to "actual armed attack" $;{ }^{2}$ imminence of attack of such high degree as to preclude effective resort by the intended victim to non-violent modalities of response has always been regarded as sufficient justification, and it is now generally recognized that a determination of imminence requires an appraisal of the total impact of an initiating state's coercive activities upon the target state's expectations about the costs of preserving its territorial integrity and political independence. ${ }^{3}$ Even the highly restrictive language of Secretary of State Webster in the Caroline case, specifying a "necessity of self defense, instant, overwhelming, leaving no choice of means and no moment for deliberation," did not require "actual armed attack," 4 and the understanding is now widespread that a test formulated in the previous century for a controversy between two friendly states is hardly relevant to contemporary controversies, involving high expectations of violence, between nuclear-armed protagonists. The requirement of proportionality, in further expression of the policy of minimizing coercion, stipulates that the responding use of the military instrument by the target state be limited in intensity and magnitude to what is reasonably necessary promptly to secure the permissible objectives of self-defense under the established conditions of necessity.

The honoring in international law of a customary right of self-defense has not meant-the point may bear emphasis-the exaltation of unilateral decision by particular states over inclusive decision by the general community. It has indeed been accepted principle that a target state may make a first, provisional decision that the conditions of necessity are such as to require it immediately to employ the military instrument for preservation of its territorial integrity and political independence. Given the

1 Fuller exposition and historical development of the principle are offered in McDougal and Feliciano, Law and Minimum World Public Order, Ch. 3 (1961). Seo also Bowett, Self-Defence in International Law (1958); Brownlie, "The Use of Force in Self-Defence," 37 Brit. Yr. Bk. of Int. Law 183 (1961).

2 Brownlie, loc. cit. note 1 above, 202, 220, 227.

3 MeDougal and Feliciano, op. cit. note 1 above, 229 et seq.

4 Mrr. Webster to Mrr. Fox, April 24, 1841, in 29 British and Foreign State Papors 1129, 1138 (1840-41). See also Jennings, "The Caroline and McLeod Cases," 32 A.J.I.L. 82 (1938). 
continuing ineffectiveness of the general community organization to act quickly and certainly for the protection of states, no other principle could be either acceptable to states or conducive to minimum order. Save for an occasional uninformed and uniformly rejected whisper, it has, however, been generally agreed that both this first provisional decision by a claimant target state and the measures it actually takes are subject to review for their necessity and proportionality by the general community of states. ${ }^{5}$ The principle of auto-interpretation, that each state is authorized to interpret customary principles, has never been applied, any more to claims of self-defense than to claims about other matters, to preclude other states from passing upon the degree to which the actions of a particular state conform to general community expectations. Fortunately, today the authority structures of the United Nations, despite all their other weaknesses, do provide quickly available and convenient fora for general community review of the lawfulness of particular claims to employ the military instrument.

The position taken by Professor Wright that Article 51 of the United Nations Charter must be construed to limit the eustomary right of selfdefense by states to reactions against "actual armed attack" would not appear to be supported by any of the commonly accepted principles for the interpretation of international agreements. It may be recalled that the appropriate goal in interpreting great constitutional agreements, such as the United Nations Charter, is that of ascertaining the genuine expectations, created by the framers and by successive appliers of the agreement, in contemporary community members about what future decisions should be; the words and behavior in the past are relevant only as they affect contemporary expectations about the requirements of future decision. There is not the slightest evidence that the framers of the United Nations Charter, by inserting one provision which expressly reserves a right of self-defense, had the intent of imposing by this provision new limitations upon the traditional right of states. ${ }^{6}$ In fact, as Professor Bowett summarizes, the preparatory work suggests "only that the article should safeguard the right of self-defence, not restrict it." 7 Thus, Committee 1/I stressed in its report, approved by both Commission I and the Plenary Conference, that "The use of arms in legitimate self defense remains admitted

\footnotetext{
5 Bromnlie, loc. cit. note 1 above, 209; MeDougal and Feliciano, op. cit. note 1 above, 218.

B The exact wording of Art. 51 may be noted: "Nothing in the present Charter shall impair the inherent right of individual or collective self-defense if an armed attack oecurs against a Nember of the United Nations, until the Security Council has taken the measures necessary to maintain international peace and security. Measures taken by Members in the exereise of this right of self-defense shall be immediately reported to the Security Couneil and shall not in any way affect the authority and responsibility of the Security Couneil under the present Charter to take at any time sueh action as it deems necessary in order to maintain or restore international peace and security."

Bowett, op. eit. note 1 above, 188. $C f$. Waldock, "The Regulation of the Use of Foree by Individual States in International Law," 81 Hague Academy Reeueil des Cours 455, 497 (1952).
} 
and unimpaired." 8 The apparent purpose of the inept language of Article 51, commonly ascribed to the late Senator Vandenburg, was only that of accommodating regional organizations, as specifically envisioned for the inter-American system by the Act of Chapultepec, with the more comprehensive, centralized system of collective security projected by the Charter. Similarly, nothing in the "plain and natural meaning" of the words of the Charter requires an interpretation that Article 51 restricts the customary right of self-defense. The proponents of such an interpretation substitute for the words "if an armed attack occurs" the very different words "if, and only if, an armed attack occurs." The fallacy in this word-juggling we have elsewhere described:

A proposition that "if $A$, then $B$ " is not equivalent to, and does not necessarily imply, the proposition that "if, and only if, $A$, then B." To read one proposition for the other, or to imply the latter from the former, may be the result of a policy choice, conscious or otherwise, or of innocent reliance upon the question-begging Latinism inclusio unius est exclusio alterius; such identification or implication is assuredly not a compulsion of logic. If a policy choice is in fact made, it should be so articulated as to permit its assessment. ${ }^{0}$

The factitious character of a reading of Article 51 to restrict the customary right of self-defense becomes even more apparent when Article 51 is related to Article 2(4), embodying the Charter's principal prohibition of force. Article 2(4) refers to both the threat and use of force and commits the Members to refrain from "threat or use of force against the territorial integrity or political independence of any state, or in any other manner inconsistent with the Purposes of the United Nations"; the customary right of defense, as limited by the requirements of necessity and proportionality, can scarcely be regarded as inconsistent with the purposes of the United Nations, and a decent respect for balance and effectiveness would suggest that a conception of impermissible coercion, which includes threats of force, should be countered with an equally comprehensive and adequate conception of permissible or defensive coercion, honoring appropriate response to threats of imminent attack. There is, further, nothing in the subsequent conduct of the parties to the agreement expressed in the United Nations Charter which would indicate genuine shared expectations that they had in Article 51 given up their customary right of self-defense ; indeed, again, the most relevant official utterances would suggest the exact opposite. ${ }^{10}$ Finally, under the hard conditions of the contemporary technology of destruction, which makes possible the complete obliteration of states with still incredible speed from still incredible dis.

8 Report of Rapporteur of Committee 1 to Commission I, 6 U.N.C.I.O. Docs. 446, 459. Discussed with further references in McDougal and Feliciano, op. cit. note 1 above, 235.

$9 \mathrm{MeDougal}$ and Feliciano, op. cit. note 1 above, 237, note 261.

10 Relevant official utterances are collected in Mallison, "Limited Naval Blockado or Quarantine-Interdiction: National and Collective Defense Claims Valid Under International Law," 31 George Washington Law Rev. 335 (1962), and in McDovitt, "The UN Charter and the Cuban Quarantine," 17 The JAG Journal 71 (1963). 
tances, the principle of effectiveness, requiring that agreements be interpreted in accordance with the major purposes and demands projected by the parties, could scarcely be served by requiring states confronted with necessity for defense to assume the posture of "sitting ducks." Any such interpretation could only make a mockery, both in its acceptability to states and in its potential application, of the Charter's major purpose of minimizing unauthorized coercion and violence across state lines.

A serious review from general community perspectives of the conditions of necessity confronting the United States when it imposed the quarantine would of course require systematic and disciplined appraisal of many features of the context of the particular events to which the United States reacted. ${ }^{11}$ Some of the more important of these features may be briefly indicated under certain category headings useful for the description of any social process, persuasive or coercive: participants, objectives, situation, base values, strategies, and outcomes.

Participants. The threat against which the United States reacted came from the Soviet Union, not Cuba. The Castro regime contributed to the threat, but more as puppet or as potential irresponsible brandisher of borrowed nuclear weapons. The suggestion by Professor Wright that in the "Cuban quarantine" the United States was dealing with "unpalatable action or attitudes of a small state" scarcely accords with reality.

Objectives. The objectives of the Soviet Union in moving major military power into the Western Hemisphere were clearly expansionist. The missiles, had their installation been achieved, would have been directly pointed toward the "territorial integrity" of all states within range. The explicit and consistent public utterances of its official spokesmen, the totalitarian character of its internal structures of authority, and the monolithic character of its demanded system of world public order raised grave question about the genuineness of the Soviet Union's dedication to the basic principle of minimum order, that violence and coercion are not to be used as instruments of expansion across state lines.

Situation. The general geographic area into which the Soviet Union was moving was one which the United States and other states in the Hemisphere had long specified, through the Monroe Doctrine and otherwise, as of especial strategic concern to them. The specific location being sought by the Soviet Union for its missiles would, in more particular, have by-passed the Dewline warning system maintained by the United States for securing advance notice of the launching of missiles from the Soviet Union.12 The by-passing of the Dewline would have grievously reduced the United States' reaction time to possible attacks from the Soviet Union, thus causing a serious disruption in the whole world balance of power between the totalitarian and non-totalitarian states. Even a few days'

11 A comprehensive and persuasive review is offered in Mallison, loc. cit. note 10 above. The requirements of "collective self-defense," not considered in this editorial, are also discussed by Mallison, as well as by MrDevitt, loc. cit. note 10 above.

12 This point, among many others, is cogently developed by MrDevitt, loc. cit. note 10 above. 
delay by the United States in taking appropriate measures would have meant that the missiles would be in place and the situation irreversible.

Expectations of crisis in the world arena as a whole were high, and estimates of prompt and effective action from the organized community of states for ameliorating particular crises were realistically low.

Bases of Power. The Soviet Union, as one of the world's two major Powers, obviously disposed of ample bases of power to put into effect the threats explicit in its behavior.

Strategies. The strategies employed by the Soviet Union included manipulation of the military instrument in its most awesome and gruesome contemporary form. Special advantage was at first sought clandestinely, but this use of the military instrument was at all times accompanied by a fanfare of other instruments-ideological, economic, and diplomaticwith an explicit promise of still more to come in all areas of the Hemisphere. The reference by Professor Wright to the shipping and installation of missiles as "trade" between the Soviet Union and Cuba in "time of peace" would appear at least mildly euphemistic.

Outcomes. The outcome almost within the grasp of the Soviet Union was that of a new, more direct military threat to the whole of the Americas, with most major cities and military bases brought within the reach of momentary nuclear destruction. The intensity of the coercion which this nearly achieved threat imposed upon the United States and the other Members of the Organization of American States was accurately reflected in the unanimity, celerity, and effectiveness with which they acted, once the character and dimensions of the threat became apparent.

Responsible appraisal from general community perspectives of the proportionality of the action taken by the United States in response to the threat from the Soviet Union must require a similarly comprehensive reference to the major features of the context of that action. We may note some of the more important features by the same headings.

Participants. Though the decision to impose the quarantine was first taken by the United States alone, quick confirmation that this decision was not an egocentric one, in the special interest of the United States only, came from the other Members of the Organization of American States in associating themselves with the United States. ${ }^{13}$

Objectives. The immediate, manifest objectives of the United States were defensive: to secure the withdrawal and elimination of nuclear weapons from Cuba. The historic precedent by which Cuba was initially set free, the generally democratic internal structures of authority in the United States, and the pluralistic world order of independent states traditionally demanded and supported by the United States did not suggest covert, expansionist objectives.

Situation. The geographic area within which the United States applied its power was located largely upon the high seas, entailing the least possible interference within' the internal territorial domain of any state.

13 The details of the action by the Organization of American States are prosonted in Mallison, and MCDevitt, loc. cit. note 10 above. 
The duration of the interference was limited to that necessary to the effectiveness of defense.

Bases of Power. The bases of power of the United States and its associates, though great, were not sufficiently disparate from those of the Soviet Union and its associates to suggest disguised duress.

Strategies. The use by the United States of the military instrument was as limited as could have been fashioned, extending only to the selective interdiction of certain types of weapons. The United States acted openly, after advance warning that the establishment of an offensive military base in Cuba would be regarded as a threat to its security. The United States immediately reported its action to the United Nations Security Couneil, asking for appropriate measures from that body.

Outcomes. The quarantine was a reversible action, causing no irremediable destruction. The employment of force which it authorized was clearly limited in intensity and magnitude to that necessary to removal of the provoking threat.

Even this impressionistic recall of some of the more salient features of the larger context of threat and response should suffice to suggest that a third-party observer, genuinely concerned to elarify the common interests of all peoples, could reasonably conclude that the action taken by the United States was in accord with traditional general community expectations about the requirements of self-defense. ${ }^{34}$ The flow of pertinent comment and decision since the incident would indeed seem to confirm that this has been the overwhelming conclusion of world public opinion. ${ }^{15}$

In a better organized world, mankind might be able to dispense with a conception of self-defense which confers upon a claimant target state as much initial discretion as does the conception so long honored in customary international law. Until that better organization is more nearly achieved, the task which confronts free peoples is, however, that of clarifying and applying a conception of self-defense which will serve their common interests in minimum order without imposing upon them paralysis in the face

14 The same conclusion is reached by Mallison, loc. cit. note 10 above, and McDevitt, loc. cit. note 10 above. See also Oliver, "International Law and the Quarantine of Cuba," 57 A.J.I.L. 373 (1963); McWhinney, "Coexistence', the Cuba Crisis, and Cold War International Law," 18 International Journal 67 (1962-63); Seligman, "The Legality of the United States Quarantine Action in Cuba," 49 A.B.A.J. 142 (1963); Larson, letter to the New York Times, Nov. 12, 1962, p. 28, cols. 5, 6; and statements by Professors Berle, Dillard, Lissitzyn, and Pugh in Columbia Lavs Schaol News, Nov. 7,1962 .

The approach in Chayes, "Law and the Quarantine of Cuba," 41 Foreign Affairs 550 (1963), and, other offeial statements, builds more upon "regional arrangement" than upon self-defense. It is hardly to be expected, however, that general community expectation will immunize even the "political" or "legislative" decisions of the Security Council in reviewing regional measures from the basic constitutional policies of necessity and proportionality.

15. It may be rememlered how the tone of professional and popular comment changed when Ambassador Stevenson introduced into the Security Council certain photographic exhibits of Soriet activities in Cuba. For a description of this oceasion, see $9 \mathrm{U} . \mathrm{N}$. Review 6, 11 (November, 1962). 
of attacks from community members who do not genuinely accept the principle of minimum order. The importance of the incident of the Soviet-Cuban quarantine is in its indication that such a clarification and application can effectively be made and that free peoples do not, as some have insisted, have to choose between the historic restraints of international law and their own survival.

Mrres S. MoDouaAL

\section{THE SIXTH COMMATTEE AND IVEW LAW}

There can no longer be doubt that a significant segment of mankind is in search of new law. This theme is on the lips of delegates of more than half of the Members of the United Nations as they speak in the Sixth Committee. What do they want in uttering the magic word "new"? The record suggests that the demand in the Sixth Committee can be understood only as a part of the appeal being voiced in all committees of the United Nations and in the specialized agencies as well. It is the reflection in law of the search for recognition of human dignity-to be achieved in part by satisfaction of economic and cultural needs such as food and literacy, and in part by recognition that the day of colonialism is over. ${ }^{1}$

Current consideration of a desirable future direction for the development of international law has evolved from this urge for recognition of human dignity through a series of stages understood only by those who have witnessed its evolution. It is personified in the item "friendly relations and cooperation among states conforming to the Charter of the United Nations" as it appeared on the agenda of the Sixth Committee during the 17th Assembly.2 This item continues to be in the forefront of the contemporary development of international law as it becomes the principal business of the Sixth Committee for the 18th Assembly ${ }^{3}$ and probably for many of the sessions that are to follow.

Superficially, the work of the Sixth Committee, especially as it has related to development of this item, has sometimes been treated as an inseparable part of the exacerbated rivalry between two hemispheres. ${ }^{4}$ This mental association is, in part, because the U.S.S.R. and its allies have been quick to appreciate the extent to which the newly developing nations of both Hemispheres are in search of new law to embody their interpretation of recognition of their aspirations. Having comprehended the revolutionary force of these aspirations with their consequent advantage to those who espouse a world of revolutionary change, statesmen of the Communistoriented states have called for the development of a new international

1 See report of Mr. Pesson (Dahomey): "It was the Committee's duty to place its greatest hopes in the future of a law which would safeguard the dignity and integrity of mankind, and for that purpose each State should act in conformity with tho principles of the Charter without looking to see whether the other States wore actually observing those principles." See U.N. Doc. Prov. A/C.6/8R. 759, pp. 3-4.

2 See General Assembly Res. 1686 (XVI), Dec. 18, 1961.

3 See General Assembly Res. 1815 (XVII), Dec. 18, 1962.

4 See report of Mr. Vasquez (Colombia), U.N. Doc. Prov. A/C.6/SR. 761, p. 15. 